\title{
Key Elements of Professional Nursing Practice: A Scoping Review
}

\author{
Novita Kurnia Sari ${ }^{1,2 *}$, Titi Savitri Prihatiningsih ${ }^{3}$, Lely Lusmilasari ${ }^{4}$ \\ ${ }^{1}$ Department of Fundamental Nursing, Nursing Management School of Nursing, Faculty of Medicine and Health Sciences, \\ Universitas Muhammadiyah Yogyakarta, Bantul, Indonesia; ${ }^{2}$ Student of Doctoral Program, Medical and Health Science, Faculty \\ of Medicine, Public Health and Nursing, Gadjah Mada University, Yogyakarta, Indonesia; ${ }^{3}$ Department of Medical Education, \\ Faculty of Medicine, Public Health and Nursing, Gadjah Mada University, Yogyakarta, Indonesia; ${ }^{4}$ Department of Nursing, \\ Faculty of Medicine, Public Health and Nursing, Gadjah Mada University Yogyakarta, Indonesia
}

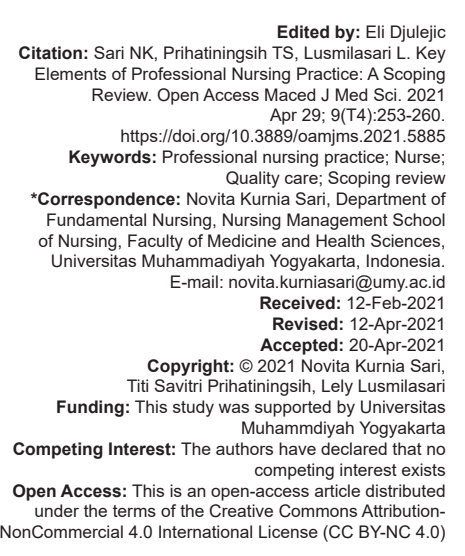

\section{Abstract}

BACKGROUND: Professional nursing practice can be used as a standard reference for implementing nursing care to help nurses provide quality care in accordance with their authorities. However, there is no standard of nursing practice that presents key elements in nursing professionalism that can be used as a reference for clinical and community practice.

AIM: The review is purposed to synthesis the pieces of literature telling the development and/or application and/or assessment of a professional nursing practice to determine the crucial elements.

METHODS: This study was guided by the following the five stages of scoping revie by Arskey and O'Malley which include (1) identifying the research question, (2) identifying relevant studies, (3) selecting studies, (4) charting the data, and (5) reporting results. Using electronic databases including ScienceDirect, EBSCO, ProQuest, PubMed, and Google Scholar within keywords of "professional nursing practice," "model," "nurse," and "conceptual framework."

RESULTS: Of a total of 3103 paper found, 28 papers were selected. From the results of the analysis, there were seven themes which the researcher used as key components of professional nursing practice, namely, (1) health system competency, (2) professional value, (3) reward and performance evaluation, (4) leadership, (5) nursing care, (6) professional development, and (7) basic care competency.

CONCLUSION: A professional nursing practice would provide the minimum standard of quality nursing practice.

\section{Background}

Nursing professional practice is described as a structure consisting of all components of the nurse's practice activities that contribute to the advancement of understanding about nursing actions in different contexts while still be based on common concepts [1]. This definition has been widely described conceptually in some scientific literature as well as by bodies or organizations that regulate the nursing profession [2], [3].

The practice of nursing professionals has a profound influence on the quality of care provided to patients. Professional nursing practice development continues to be carried out by experts, the goal is of course for the provision of nursing care to reach predetermined standards, maintain patient safety, and ensure patient outcomes.

Various components of nursing professional practice have been developed and used in various service settings [4], [5], [6]. For example, Hoffart and Wood developed a component of the Professional Practice Model which consists of six domains, namely, 'leadership, nurses' independent and collaboration practice, environment, research/innovation, nurse development and reward, and patient outcome" [7]. This model is used in the United States which has been adopted and modified for use in care settings and other countries [8], [9], [10] Meanwhile, Xing, et al. used six elements of professional nursing practice that are used specifically for the handling of patients with diabetes in China. The components consist of diabetes professional knowledge, diabetes-related knowledge, communication skills and health education abilities, specialized skills, and clinical judgment [11].

At present, several studies have described these components using different model approaches and in various service settings. However, there is no reference that summarizes what components should be present in professional nursing practice in general. Therefore, there is a need to synthesize available evidence on professional nursing practice.

The objectives of this scoping review are (1) to identify the most recent publication of scientific literature on the development/implementation/evaluation of professional nursing practice and (2) to synthesize the elements of professional nursing practice. 


\section{Methods}

The scoping review approach was used in this study to review the literature of scientific works and to define the main concepts used to describe components of professional nursing practice. This method was chosen because it was able to study and map out existing topics in a wider manner by ignoring the study design [12]. This method also makes it possible to extract different data and develop it in a meaningful, transparent, and systematic way [13].

To ensure the credibility and robustness in this study, the scoping Review utilized by Arskey and O'Malley in the methodological framework [12]. This includes five stages of approach and the principles of knowledge synthesis invented by Levac et al., which include "(1) identifying the research question, (2) identifying relevant studies, (3) selecting studies, (4) charting the data, and (5) reporting results" [12], [14].

\section{Stage 1: Identifying research question}

The research question is what are the components in professional nursing practice?

\section{Stage 2: Identifying relevant studies}

Search strategy included of five electronic databases: SienceDirect, EBSCO, ProQuest, PubMed, and Google Scholar within keywords of "professional nursing practice" AND "model" AND "nurse" AND "conceptual framework." The following chart is how to select articles in this review in Figure 1. The inclusion criteria are articles published between January 1, 2016, and January 31, 2020, written in English, full-text included, and that provided information about the approaches to development and/or implementation and/or evaluation. The exclusion criteria are duplicated and abstract only.

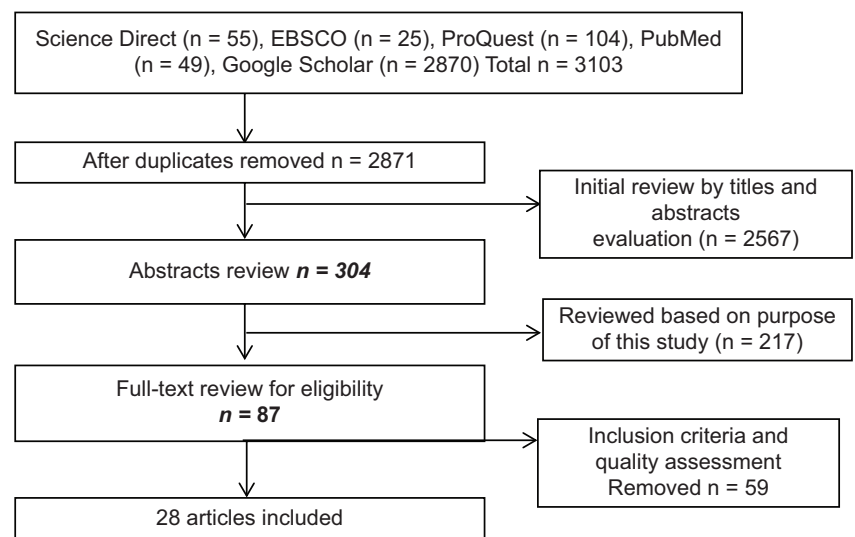

Figure 1: Flowchart of search strategy and selection process

\section{Stage 3: Selecting studies}

Three authors independently screened article titles and abstracts to identify relevant articles according to inclusion criteria. There were 87 articles. After reading and reviewing the full text articles, 28 articles were obtained for analysis. The differences in the views of the three researchers were resolved by joint discussion.

\section{Stage 4: Charting the data}

The research, studies, and literature that are included were reviewed to extract the data: (1) Setting, (2) Methods: development/implementation/evaluation, (3) Sample/Target, and (4) Key elements. Descriptive data that have been extracted are then analyzed using thematic analysis [15]. Each article is read carefully and then classified into certain themes of the data that specifically described the components. The three researchers conducted an analysis independently. Inconsistencies were resolved by joint review.

\section{Results}

This section represents the Stage 5 of the scoping review approach, namely, result report. Of the 87 eligible full texts, there are 28 articles that can be reviewed in this scoping review. The data which were presented on Table 1 contained author, year, location and setting, method, sample/target, and key component of professional nursing practice. There were based on PRISMA Table 1. The summary of articles about the components of professional nursing practice $(n=29)$.

The majority of the studies were developed in the USA (ten studies), with others being from Ireland (one study), Canada (two studies), Australia (one study), Asia (two studies), Middle East (three studies), Portugal (two studies), Colombia (one studies), North America (one studies), and undescribed the location (five studies). Service settings used start from unit based [4], [16] mostly hospital based [5], [6], [10], [17], [18], [19], [20], [21], [22], [23], [24], [25], [26], [27], [28], community based [29], [30], to systems based in healthcare systems [11], [31], [32].

From the results of the analysis, there were seven themes which the researcher used as key components of professional nursing practice, namely, (1) health system competency, (2) professional value, (3) reward and performance evaluation, (4) leadership, (5) nursing care, (6) professional development, and (7) basic care competency.

\section{Health system competency}

This health system competency is closely related to the ability of nurses to understand existing health policies and systems [4], [18], [21], [33], 
Table 1: The summary of articles about the components of professional nursing practice $(n=28)$

\begin{tabular}{|c|c|c|c|c|}
\hline No. & Author (year) & Location and Settings & Method & Sample/Target \\
\hline 1. & $\begin{array}{l}\text { Cordo and } \\
\text { Hill-Rodriguez } \\
\text { (2017) }\end{array}$ & $\begin{array}{l}\text { Florida } \\
\text { Hospital, USA } \\
\text { Hospital based }\end{array}$ & $\begin{array}{l}\text { Development of Professional } \\
\text { Practice Model (PPM) }\end{array}$ & Staff Nurses \\
\hline 2. & $\begin{array}{l}\text { DeMarco and } \\
\text { Pasadino (2018) }\end{array}$ & $\begin{array}{l}\text { NYU Langone Hospital } \\
\text { Center USA } \\
\text { Hospital Based }\end{array}$ & $\begin{array}{l}\text { Development of A Clinical } \\
\text { Ladder Program based on the } \\
\text { American Nurses Association's } \\
\text { Standards of Clinical Nursing }\end{array}$ & $\begin{array}{l}\text { Senior RN Clinicians } \\
\text { RN Clinicians } \\
\text { Senior RN Staff } \\
\text { RN Staff }\end{array}$ \\
\hline 3. & $\begin{array}{l}\text { Joseph and Bogue } \\
\text { (2016) }\end{array}$ & $\begin{array}{l}\text { USA } \\
\text { Hospital Based }\end{array}$ & $\begin{array}{l}\text { Model Development and } \\
\text { Implementation of Nursing } \\
\text { Shared Governance }\end{array}$ & $\begin{array}{l}\text { Clinical Nurse } \\
\text { NPC Chairs and } \\
\text { Members } \\
\text { Managers } \\
\text { Directors } \\
\text { System Executives }\end{array}$ \\
\hline 4. & Keyko et al. (2016) & General/Undefined & $\begin{array}{l}\text { Evaluation of work engagement } \\
\text { in professional nursing practice }\end{array}$ & Organizational Climate \\
\hline
\end{tabular}
using a systematic review

Patient, families, and global community; Nursing professionalism and value; Recognition and reward; Leadership; patient care delivery and outcome

Teamwork and collaboration; Patient centered care; New knowledge; Quality improvement and peer review; Informatics; Safety; Education

Leadership (Communication; Controlling the effects of environmental force; Goals/outcomes; Nursing position; Empowerment capacity; Group empowerment; Resources; Nursing role)

Organizational Climate (Leadership, Structural Empowerment); Job Resources (Organizational, "Interpersonal and Social relations, Organization of Work and Tasks); Professional Resources (Professional Practice Environment, Autonomy, Role and Identity, Professional Practice and Development, Personal Resources, Psychological, Relational, Skill); Job Demands (Work Pressure, Adverse Environment, Physical and Mental Demands, Emotional Demands)"; Outcomes (Performance and Care, Professional, Personal) Interpret important information; Understand relations of information and data; Expect such relations; Necessary intervention; Need of theory for practice; Quality of care

5. Ribeiro et al. (2018) Portugal Hospital Based

6. Shear and Shakir USA (2017) Hospital based

7. Hermida and Sanchez-Herrera (2018)

8. Reed, Fitzgerald, Bogota, Colombia Hospital based and Bish (2017) Community based

9. Dery et al. (2017) Canada Hospital based

10. Dimitroff et al. USA (2016) Hospital based

11. Hossli et al. (2018) USA Unit based

12. Meehan and Timmins (2018) General/Undefined (2019) General/Undefined

Evaluation of Public Cooperation 56 Nurse Model using qualitative study

Implementation of Patient Caring Touch System (PCTS) introduced by Army Nurse Corps well as Medical Staff Implementation of Nursing Care 145 Nurses with a Human Approach Model

Development of Practice Model utilizing sequential methods of a pragmatic philosophy and nurse agency theory

Evaluation of Enacted Scope of 301 nurses Nursing Practice

Evaluation of RNs' Values and $66 \mathrm{RNs}$ Professional Practice Model (PPM) using FG Implementation and Evaluation 160 Ambulatory Care of Clinical Advancement System Nurses (CAS) based on Benner Mode and the foundation of PPM

Development of Careful Nursing Clinical Practice Philosophy and PPM

Development of the Professional Nurse Managers Values Model using Literature Review

14. Davidson et al Ethical Nursing Practice Development of Social (2018) General/Undefined ecological framework using Literature Review

15. Kim et al. (2017) Seoul, Korea Hospital based

Development and validation of a nursing professionalism evaluation model

16. Xing et al. (2019) Diabetes Care in China The development of a standardized framework using a delphi study

17. Slatyer et al. (2016) General/Undefined Evaluation of PPMs for nursing Nurses in genera using literature review

18. Mensik et al. (2017) Magnet Organization, Evaluation of PPM Hospitals in USA Hospital Based

19. Weis and Schank (2017)

Commission on Collegiate Nursing Education and $\mathrm{A}$ major health care system, USA

System based

Development and Psychometric Evaluation of the Nurses Professional Values Scale-3 (NPVS-3)

20. Blakeman, Undefined Chambell and Unit Based Tobar (2017)
Development and Implementation of a Professional Practice Mode Through Nursing Salons
Nurses in general

Enhanced communication; Capability building; Evidence based practice; Healthy work environment; Patient advocacy

Humanization in care; Risk management; Knowledge management; Technology management

Respect; Willing; Knowing; Supported; Emotional intelligent; Moral agency

Assessment and care planning; Teaching of patient and families; Communication and care coordination; Integration and supervision of staff; Quality of care and patient safety; Knowledge updating utilization Nurse autonomy; Nurse accountability; Professional development and continuing education; High quality care; Continuity in patient care; Commitment to service; Critical thinking

Critical contribution to organization; Unique skill/specialty of Ambulatory Care; Leadership Engagement of Leader and Nurses Staff

Therapeutic milieu; Practice competence and excellence; Managemen of practice and influence in Health System; Professional Authority Nursing care quality (Nurses job satisfaction, Patient satisfaction); Individual values (Prior experience, Perceptions of health and illness, Needs and priorities); Professional values (Truth, Integrity, Altruism, Autonomy, Equality, Human dignity, Aesthetics)

"Individual factors (patients and families); Individual factors (nurses); Relationships between health care professionals; Relationships between patients and nurses; Organizational health care context; Professional and education regulation and standards; Community; Social, political, and economic".

200 Nurses

Scientific competence, Technical competence; Ethical competence; Aesthetic competence; Existential competence; Self-motivation; Contribution; Future plans (growth potential); Nursing Philosophy (conviction); Patient Care; Human Resources Development; Leadership Diabetes "professional knowledge; Diabetes-related knowledge; Communication skills and health education abilities; Specialized skills; Clinical Judgment"; Specialty development capacity

"Leadership; Nurses' independent and collaborative practice; Environment; Nurse development and reward; Research/innovation; Patient outcomes".

982 RNs (direct care, leaders/managers, other nurses and non-nurse

Pontribution to our patients "(Assessment, Diagnosis, Outcome identification, Planning, Implementation, Evaluation); Contribution to our profession (Environmental health, Leadership, Resource utilization, EBP and research, Collaboration, Culturally congruent practice, Communication, Ethics, Quality of practice, Education, Professional practice evaluation); Contribution to society (Safe, Equitable, Efficient, Effective, Timely)" Caring ("Respect the worth and dignity of all; nature of health and right including baccalaureate to self-determination, Commitment to patient/populations; collaborative $\begin{array}{ll}\text { including baccalaureate } & \text { to self-determination, Commitment to patient/populations; collaborative } \\ \text { nursing students, } & \text { partnerships, Environment conducive to safe, high-quality conditions }\end{array}$ graduate nursing for patients and staff); Activism (Act as patient advocate; performance students, and practicing standards and safety, Authority, accountability and responsibility for nurses nursing actions; promote health and quality care, Health diplomacy for human rights); Professionalism (Personal responsibility for personal/ professional self, Advancement of profession through research, standard development, and policy, Responsibility of professional nursing organizations for impacting global health policy")

Direct care nurses/ Relationship-based care, defined as a "therapeutic relationship between the nurse and the patient/family and essential to provide exceptional and compassionate care; Respect and core values, which were identified as "key to supporting nursing practice;" The achievement of optimal patient outcomes 
Table 1: (Continued)

\begin{tabular}{|c|c|c|c|c|c|}
\hline No. & Author (year) & Location and Settings & Method & Sample/Target & Key Components \\
\hline 21. & Ribeiro et al. (2018) & Portugal & $\begin{array}{l}\text { Development of the grounding of } \\
\text { the professional nursing practice } \\
\text { using Explanatory approach }\end{array}$ & 56 urses & $\begin{array}{l}\text { Structure (Organizational Resources, Human Resources, Material } \\
\text { Resources, Service Organization, Sustainability of Nursing Practice, } \\
\text { Organization of Nursing Practice); Process (Decision-making Process, } \\
\text { Role-model of Professional Practice, Scientific Methodology of } \\
\text { Professional care process, Communication process, Collaborative } \\
\text { practice, Management process); Result (Client Results, Nurses Results) }\end{array}$ \\
\hline 22. & $\begin{array}{l}\text { Heydari et al. } \\
\text { (2016) }\end{array}$ & $\begin{array}{l}\text { Iran } \\
\text { Hospital Based }\end{array}$ & $\begin{array}{l}\text { Evaluation of nurses' } \\
\text { professional competence using a } \\
\text { cross-sectional study }\end{array}$ & 220 nurses & $\begin{array}{l}\text { Helping role; Teaching-coaching; Diagnostic functions; Managing } \\
\text { situation; Therapeutic interventions; Ensuring quality; Work role }\end{array}$ \\
\hline 23. & $\begin{array}{l}\text { Kahya and Oral } \\
(2018)\end{array}$ & $\begin{array}{l}\text { Turkey } \\
\text { Hospital and Clinic } \\
\text { based }\end{array}$ & $\begin{array}{l}\text { Development of clinical nurse } \\
\text { performance measurement } \\
\text { including contextual items using } \\
\text { a cross-sectional study }\end{array}$ & $\begin{array}{l}233 \text { clinical nurses } \\
\text { (nursing directors, all } \\
\text { supervisor nurses, and } \\
\text { one of each five nurses } \\
\text { (randomly) in each unit) }\end{array}$ & $\begin{array}{l}\text { Contextual; Professional skills; Clinical skills; Communication; Problem } \\
\text { solving; Professional ethics; Teamwork; Leadership }\end{array}$ \\
\hline 24. & Braithwaite (2016) & $\begin{array}{l}\text { Ontario, Canada } \\
\text { Primary Care Based }\end{array}$ & $\begin{array}{l}\text { Evaluation of scope of practice } \\
\text { enactment using reviews and a } \\
\text { cross-sectional study }\end{array}$ & 178 Primary Care RNs & $\begin{array}{l}\text { Assessment and care planning; Teaching of patients and families; } \\
\text { Communication and care coordination; Integration and supervision of staff; } \\
\text { Quality of care and patient safety; Knowledge utilization and updating }\end{array}$ \\
\hline 25. & $\begin{array}{l}\text { Zeleníková et al. } \\
\text { (2020) }\end{array}$ & $\begin{array}{l}\text { Nine Czech Hospitals } \\
\text { Hospital based }\end{array}$ & $\begin{array}{l}\text { Evaluation nurses' perception } \\
\text { of Professional Practice } \\
\text { Environment }\end{array}$ & $\begin{array}{l}513 \text { general and } \\
\text { practical nurses } \\
\text { providing direct care }\end{array}$ & $\begin{array}{l}\text { "Leadership and autonomy in clinical practice;" "Control over practice;" } \\
\text { Communication about the patients; Teamwork; "Handling disagreements; } \\
\text { Staff relationship; Internal work motivation; Cultural Sensitivity" }\end{array}$ \\
\hline 27. & Raghubir (2018) & $\begin{array}{l}\text { North America } \\
\text { Advance nursing } \\
\text { practice based }\end{array}$ & $\begin{array}{l}\text { Evaluation of emotional } \\
\text { intelligence in professional } \\
\text { nursing practice using a } \\
\text { concept review using Rodgers's } \\
\text { evolutionary analysis approach }\end{array}$ & $\begin{array}{l}\text { Advanced Practice } \\
\text { Nurses }\end{array}$ & $\begin{array}{l}\text { Emotional Intelligence (Self-awareness, Self-management, Social } \\
\text { awareness, Social/relationship management); Nursing Practice (The } \\
\text { quality of patient care and outcomes, Decision-making, Critical thinking, } \\
\text { Overall the well-being of practicing nurses) }\end{array}$ \\
\hline 28. & $\begin{array}{l}\text { Porter-O'Grady and } \\
\text { Clavelle (2019) }\end{array}$ & $\begin{array}{l}\text { United States, Europe, } \\
\text { Australia, and New } \\
\text { Zealand } \\
\text { General/Undefined }\end{array}$ & $\begin{array}{l}\text { Development of the Structural } \\
\text { Framework for Nursing } \\
\text { Professional Governance }\end{array}$ & General Nurses & $\begin{array}{l}\text { Accountability; Professional obligation; Collateral relationships; Effective } \\
\text { decision making }\end{array}$ \\
\hline
\end{tabular}

contribute to the organization and community [17], [23], [24], [25], [34], and culturally competence in nursing practice [25], [28], [35].

\section{Professional value}

We mentioned that at least nine authors determined professionalism as a component of professional nursing practice [6], [17], [19], [20], [31], [35], [36], [37]. Other terms used to express professional value include ethical competence [19], [24], [28], caring [20], [22], [29], [31], and role and commitment [19], [29], [37].

\section{Reward and performance evaluation}

Eight related studies state that reward and punishment are part of professional nursing practice [8], [17], [19], [20], [25], [33], [38]. These two things are outcomes that need to be considered when nurses have carried out nursing practice in accordance with predetermined standards [19]. The form of reward given can be in the form of recognition from the workplace based on the results of the performance evaluation [17].

\section{Leadership}

In principle, nurses are leaders, not only on a work organization scale but also in managing nursing care for patients. There are 28 authors who state that the components of professional nursing practice are leadership. Ten authors explicitly mention it [4], [6], [8], [10], [17], [19], [24], [25], [28], [38]. Others explain the leadership domain which consists of decision making, collaboration, teamwork, supervision, and coordination [5], [18], [22], [28], [37], [30].

\section{Nursing care}

This term nursing care refers to an activity for patient care delivery [5], [17], [24], [30], [32], [36], [39]. Almost all authors include nursing care as a vital element of professional nursing practice. Nursing care implementation cannot be separated from the clinical skills possessed by each nurse [4], [6], [11], [19]. Nurses must not only be able to provide good and skilled nursing care but also nurses are required to ensure that the care they provide is quality so that patient outcomes can be achieved [8], [23], [27], [29].

\section{Professional development}

There are 13 authors who state that professional development is a component of professional nursing practice. There are at least three terms used to explain this, (1) continuing education [11], [18], [23], [25], [39]; (2) research/innovation [4], [6], [28], and (3) selfimprovement [21], [24], [20], [27], [30].

\section{Basic care competency}

Besides having to be able to master nursing practice well, nurses are also required to have basic care competency which is used as a complement so that the care provided to patients is more comprehensive researchers [20], scientific competency [24], [25], and organizational skills [20], [21]. 


\section{Discussion}

Based on this scoping review, it can be seen that in the past 5 years there have been development and/or implementation and/or evaluation in several countries. Ten articles came from other USA from countries in Australia, UK, Middle East, and Asia. USA the most, this is possible because the health policy in the USA has been very well regulated. Nursing practice standards have been compiled to ensure high standards of nursing practice, promoting a safe, and ethical work environment, bolstering the health and wellness of nurses, and advocating on healthcare issues that affect nurses and the public [40], [41]. Also relevant to the nursing workforce arrangement where $60 \%$ of nurses in the US work in hospitals, the results of this study also show the same thing that the development and/or implementation and/or evaluation of professional nursing practice is carried out in hospital based [5], [6], [10], [17], [18], [19], [20], [21], [22], [23], [24], [25], [26], [27], [28].

This scoping review focuses on identifying the components of professional nursing practice. The results obtained were seven components of professional nursing practice.

\section{Health system competency}

To be able to do nursing practice appropriately, nurses are expected to master and understand the existing health systems both regionally and globally. Wilson et al. stated that the impact of globalization on social, political, economic, and even environmental conditions will have an impact on health problems for individuals and communities [42]. Health system competencies that must be mastered include global burden of disease, globalization of health and healthcare, healthcare in low-resource settings, social justice, cultural, and religious practice [43].

\section{Professional value}

Nurse's professional values reflect an understanding of the care given to patients [44]. The professional value of nurses is directly proportional to the perception and levels of education, the better the perception and level of education, the stronger the professional value they have [45]. Elliot in his integrative literature identifies professional value into two categories "1) other-oriented values (caring and compassion, respect for human dignity, advocacy and altruism, collaboration, professional advocacy, confidentiality, safety, and quality) and 2) selforiented values (social justice and activism, integrity and honesty, competency and professional growth, authority, accountability, and caring for the self)" [46].

\section{Reward and performance evaluation}

Cempakasari et al. stated that reward is one of the factors that affect the performance of nurses in providing nursing care [47]. Performance evaluation is a series of activities that need attention by management, including the assessment method used [48]. The performance of nurses in carrying out nursing care to patients has an impact on the overall performance of the identified at least seven authors who mentioned this term. These competencies include technical competency [18], [22].

Health service system: The better the nurse's performance, the better the quality of service provided [49]

\section{Leadership}

In providing nursing care to patients, nurses are required to be able to influence patients through the attitudes displayed so that they have a good effect on patient care. This ability is called leadership [50]. Through leadership skills, nurses can indirectly increase the competence of nurses to carry out professional nursing practice [51]. Nurse leadership skills are not only needed when caring for patients but organizationally will also have an impact. Heinen et al. in their integrative review explained that there are four domains, namely, clinical leadership, professional leadership, health system leadership, and health policy leadership [52].

\section{Nursing care}

Nurses' clinical skills are at the core of the nursing profession, so all nurses must be competent to perform them. To achieve the expected standard, it is not enough for nurses to have clinical skills but also need to demonstrate ability in special skills [39], ensure high quality of practice [53], and collaborating with other health-care professionals [54].

\section{Professional development}

Professional development that is meant here is continuing education, conduct research/innovation, and self-improvement. Health problems and changes in service systems globally require nurses to continue to develop themselves. Then professional development should be the responsibility of each nurse so that the care given to patients is guaranteed quality, safety, and based on evidence based [55]. In addition to better quality patient care, professional development is also useful for maintaining competence and enhancing nursing careers [56].

\section{Basic care competency}

Based on the results of the review, the terms for this component consist of (1) technical competence which 
includes mastery of technology and information systems as well as the ability to use modern medical devices. Technological innovation in nursing services continues to grow. Nurses are required to continue to improve their competence [57]. (2) Scientific competence in the form of nurses' ability to provide care based on evidence-based practice. The better the nurses carry out care based on evidence based practice, the better the quality of care, safety, and patient outcomes can be ensured [58].

\section{Strength and limitation}

A strength of this scoping review is that the search was very comprehensive including the development and/or implementation and/or evaluation of nursing professional practice model or framework. This review was conducted according to the standard of methodology. However, there are limitations of the scoping review. Date and language limitations that we set may affect the currency of the study and may have excluded some topics.

\section{Conclusion}

This scoping review provides an important resource for nurse managers who seek the component of professional nursing practice for excellence nursing service. The key component of professional nursing practice is clearly described. It is important to provide the description of each component in the context of nursing to ensure the understanding of the component.

\section{Acknowledgment}

The authors would like to thank Universitas Muhammdiyah Yogyakarta for its financial contribution and Gadjah Mada University for its direct supports in this project.

\section{References}

1. Poitras ME, Chouinard MC, Fortin M, Gallagher F. How to report professional practice in nursing? A scoping review. BMC Nurs. 2016;15:31. https://doi.org/10.1186/s12912-016-0154-6 PMid:27231437

2. Girard F, Linton N, Besner J. Professional practice in nursing: A framework. Nurs Leadersh. 2005;18(2):1.

3. American Nurses Association. Nursing Scope and Standards of Practice. $3^{\text {rd }}$ ed. Maryland: Nursesbooks; 2015.
4. HossliSM, Start R, Murphy MP. Implementation and evaluation of an ambulatory care nurse clinical advancement system. Nurs Econ. 2018;36(3):149-55.

5. Dery J, Clarke S, D'Amour D, Blais R. Scope of nursing practice in a tertiary pediatric setting: Association with nurse and job characteristics and job satisfaction. J Nurs Scholarsh. 2018;50(1):56-64. https://doi.org/10.1111/jnu.12352

6. Kahya E, Oral N. Measurement of clinical nurse performance: Developing a tool including contextual items. J Nurs Educ Pract. 2018;8(6):112-23.

7. Hoffart N, Wood CQ. Elements of a nursing professional practice model. J Prof Nurs. 1996;12(6):354-64.

PMid:8979639

8. Ribeiro OM, da Silva Martins MM, Tronchin DM. Nursing professional practice models: An integrative literature review. $\mathrm{J}$ Nurs Ref. 2016;4(10):125-33.

9. Webster J, Cowart P. An innovative professional nursing practice model. Nurs Adm Q. 1999;23(3):11-6. PMid: 10363015

10. Joseph ML, Bogue RJ. A theory-based approach to nursing shared governance. Nurs Outlook. 2016;64(4):339-51. https:// doi.org/10.1016/j.outlook.2016.01.004 PMid:27005400

11. Xing $Q$, Zhang $M$, Zhao $F$, Zhou $Y$, Mo $Y$, Yuan L. The development of a standardized framework for primary nurse specialists in Diabetes Care in China: A delphi study. J Nurs Res. 2019;27(6):e53. https://doi.org/10.1097/jnr.0000000000000330 PMid:31162295

12. Arskey $\mathrm{H}, \mathrm{O}$ 'Malley L. Scoping studies: Towards a methodological framework. Int J Soc Res Methodol. 2005;8(1):19-32.

13. Grant MJ, Booth A. A typology of reviews: An analysis of 14 review types and associated methodologies. Health Info Libr J. 2009;26(2):91-108. https://doi. org/10.1111/j.1471-1842.2009.00848.x

PMid: 19490148

14. Levac D, Colquhoun H, O'Brien KK. Scoping studies: Advancing the methodology. Implement Sci. 2010;5:69. https://doi. org/10.1097/nna.0000000000000370 PMid:20854677

15. Braun V, Clarke V. Using thematic analysis in psychology. Qual Res Psychol. 2006;3(2):77-101

16. Hodge MB, Campbell $P$, Tobar $K$. Engaging nurses in the development and implementation of a professional practice model through nursing salons. J Nurs Adm. 2016;46(9):425-7. PMid:27556650

17. Cordo J, Hill-Rodriguez D. The evolution of a nurse professional practice model through leadership support of clinical nurse engagement, empowerment, and shared decision making. Nurse Lead. 2017;15(5):325-30. https://doi.org/10.1016/j. $\mathrm{mnl} .2017 .07 .009$

18. DeMarco K, Pasadino F. Transforming a nurse practice advancement program for the new millenium. Nurse Lead. 2018;16(4):234-9. https://doi.org/10.1016/j.mnl.2018.05.010

19. Keyko K, Cummings GG, Yonge O, Wong CA. Work employee in professional nursing practice: A systematic review. Int J Nurs Stud. 2016;61:142-64. https://doi.org/10.1016/j. ijnurstu.2016.06.003

PMid:27351831

20. Ribeiro O, Martins MM, Tronchin DM, da Silva JM. Professional nursing practice grounded in the theoretical framework of the discipline: Reality or utopia. Rev Enferm Ref. 2018;4(19):39-48. https://doi.org/10.12707/riv18040

21. Shear K, Shakir A. The patient caring touch system: A framework for positive practice environment. Med Surg Nurs. 
2017;26(3):215-8.

22. Hermida EY, Sanchez-Herrera B. Nursing care with a human approach:A model for practice with service excellence. Aquichan. 2018;18(2):149-59. https://doi.org/10.5294/aqui.2018.18.2.3

23. Dimitroff LJ, Tydings DM, Nickoley S, Nichols LW, Krenzer ME. From blank canvas to masterwork: Creating a professional practice model at a magnet hospital. Nurs Res Pract. 2016;2016:8783594. https://doi.org/10.1155/2016/8783594 PMid:28097022

24. Kim YH, Jung YS, Min J, Song EY, Ok JH, Lim C, et al. Development and validation of a nursing professionalism evaluation model in a career ladder system. PLoS One. 2017;12(10):e0186310. https://doi.org/10.1371/journal. pone. 0186310

PMid:29023537

25. Mensik JS, Martin DM, Johnson KL, Clark CM, Trifanoff CM. Embedding a professional practice model across a system. J Nurs Adm. 2017;47(9):421-5. https://doi.org/10.1097/ nna.0000000000000508

PMid:28834803

26. Ribeiro OM, Martins MM, Tronchin DM, da Silva JM. Explanatory approach to the grounding of the professional nursing practice. Supl Digits Rev ROL Enferm. 2018;41(11-12):173-80.

27. Heydari A, Kareshki H, Armat MR. Is nurses' professional competence related to their personality and emotional intelligence? A cross-sectional study. J Caring Sci. 2016;5(2):121-32. https://doi.org/10.15171/jcs.2016.013 PMid:27354976

28. Zelenikova R, Jarosova D, Plenova I, Janikova E. Nurses' perceptions of professional practice environment and its relation to missed nursing care and nurse satisfaction. Int $\mathrm{J}$ Environ Res Public Health. 2020;17(11):3805. https://doi.org/10.3390/ ijerph17113805

PMid:32471133

29. Reed FM, Fitzgerals L, Bish MR. A practice model for rural district nursing success in end-of-life advocacy care. Scand $J$ Caring Sci. 2018;32:746-55. https://doi.org/10.1111/scs.12505 PMid:28840608

30. Braithwaite SE. Measuring Scope of Practice Enactment among Primary Care Registered Nurses in Ontario, Queen's Graduate Theses and Dissertations School Nursing; 2016.

31. Weis D, Schank MJ. Development and psychometric evaluation of the nurses professional values scale-3. J Nurs Meas. 2017;25(3):400-10. https://doi.org/10.1891/1061-3749.25.3.400 PMid:29268825

32. Raghubir AE. Emotional intelligence in professional nursing practice: A concept review using Rodgers's evolutionary analysis approach. Int J Nurs Sci. 2018;5:126-30. https://doi. org/10.1016/j.ijnss.2018.03.004

PMid:31497624

33. Kaya A, Boz I. The development of the professional values model in nursing. Nurs Ethics. 2016;26(3):914-23. https://doi. org/10.1177/0969733017730685 PMid:28929939

34. Mensik JS, Martin DM, Scott KA, Horton K. Development of a professional nursing framework: The journey toward nursing excellence. J Nurs Adm. 2011;41(6):259-64. https://doi. org/10.1097/nna.0b013e31821c460a PMid:21610480

35. Davidson $P$, Rushton $\mathrm{CH}$, Kurtz $\mathrm{M}$, Wise $\mathrm{B}$, Jackson $\mathrm{D}$, Beaman A, et al. A social-ecological framework: A model for addressing ethical practice in nursing. J Clin Nurs. 2018;27(56):1233-41. https://doi.org/10.1111/jocn.14158

36. Meehan TC, Timmins F, Burke J. Fundamental care guided by the careful nursing philosophy and professional practice model. J Clin Nurs. 2018;27(11-12):2260-73. https://doi.org/10.1111/ jocn. 14303

\section{PMid:29399916}

37. Porter-O'Grady T, Clavelle JT. The structural framework for nursing professional governance: Foundation for empowerment. Nurse Lead. 2020;18(2):181-9. https://doi.org/10.1016/j. $\mathrm{mnl} .2019 .08 .004$

38. Twigg DE, Davis SM, Slatyer S, Coventry LL. From $27^{\text {th }}$ International Nursing Research Conggress: Identifying Key Components of Professional Practice Models for Nursing: A Synthesis of Literature; 2016. https://doi.org/10.1111/ jonm.12309

39. Slatyer S, Conventry LL, Twigg D, Davis S. Professional practice models for nursing: A review of the literature and synthesis of key components. J Nurs Manag. 2016;24(2):139-50. https://doi. org/10.1111/jonm.12309

PMid:25975609

40. American Nurses Association, Health Policy; 2020. Available from: https//www.nursingworld.org/practice-policy/healthpolicy. [Last accessed on 2020 May 16].

41. American Nurses Association, Recognition of a Nursing Specialty, Approval of a Specialty Nursing Scope of Practice Statement, Acknowledgment of Specialty Nursing Standards of Practice, and Affirmation of Focused Practice Competencies; 2017. https://doi.org/10.1097/cin.0000000000000150

42. Wilson L, Moran L, Zarate R, Warren N, Ventura CA, TamíMaury I, et al. Qualitative description of global health nursing competencies by nursing faculty in Africa and the Americas. Rev Lat Am Enfermagem. 2016;24:e2697. https://doi. org/10.1590/1518-8345.0772.2697

\section{PMid:27276020}

43. Wilson L, Harper DC, Tami-Maury I, Zarate R, Salas S, Farley J, et al. Global health competencies for nurses in the Americas. J Prof Nurs. 2012;28(4):213-22. https://doi.org/10.1016/j. profnurs.2011.11.021 PMid:22818191

44. Erkus G, Dinc L. Turkish nurses' perceptions of professional values. J Prof Nurs. 2018;34(3):226-32. https://doi.org/10.1016/j. profnurs.2017.07.011 PMid:29929805

45. Kantek F, Kaya A, Gezer N. The effects of nursing education on professional values: A longitudinal study. Nurse Educ Today. 2017;58:43-6. https://doi.org/10.1016/j.nedt.2017.08.004 PMid:28866254

46. Elliot AM. Identifying professional values in nursing: An integrative review. Teach Learn Nurs. 2017;12(3):201-16.

47. Cempakasari AR, Nopiyani NM, Duarsa DP. Association between nursing care performance with perception of financial rewards, career development and supervision. Public Health Prev Med Arch. 2019;7(1):3-7. https://doi.org/10.15562/phpma. v7i1.184

48. Moradi T, Mehraban MA, Moeini M. Comparison of the perceptions of managers and nursing staff toward performance appraisal. Iran J Nurs Midwifery Res. 2017;22(2):128-34. https:// doi.org/10.4103/ijnmr.ijnmr_142_15 PMid:28584551

49. Ferreira CA, Neto MT, Vasconcelos FC, Souki GQ. Motivation and rewards to health professionals. Rev Gest Planej. 2016;17(1):41-58.

50. Maziero VG, Bernandes A, Righetti EA, Spiri WC, Gabriel CS. Positive aspects of authentic leadership in nursing work: Integrative review. Rev Bras Enferm. 2020;73(6):e20190118. https://doi.org/10.1590/0034-7167-2019-0118

PMid:32785461 
51. de Moura AA, Bernardes A, Balsanelli AP, Zanetti AC, Gabriel CS. Leadership and nursing work satisfaction: An integrative review. Acta Paul Enferm. 2017;30(4):442-50. https://doi.org/10.1590/1982-0194201700055

52. Heinen M, van Oostveen C, Peters J, Vermeulen H, Huis A. An integrative review of leadership competencies and attributes in advance nursing practice. J Adv Nurs. 2019;75(11):2378-92. https://doi.org/10.1590/1982-0194201700055

PMid:31162695

53. Connolly $D$, Wright $F$. The nursing quality indicator framework tool. Int J Health Care Qual Assur. 2017;30(7):603-16.

PMid:28809586

54. Martins A, Manley K. Developing standards for an integrated approach to workplace facilitation for interprofessional teams in health and social care contexts: A delphi study. J Interprof Care. 2018;32(1):41-51. https://doi.org/10.1080/13561820.201 7.1373080

PMid:29058564
55. Cooper E, Spilsbury K, McCaughan D, Thompson C, Butterworth T, Hanratty B. Priorities for the professional development of registered nurses in nursing homes: A delphi study. Age Aging. 2017;46(1):39-45. https://doi.org/10.1093/ageing/afw160 PMid:28181630

56. Price $\mathrm{S}$, Reichert $\mathrm{C}$. The importance of continuing professional development to career satisfaction and patient care: Meeting the needs of novice to mid-to late-career nurses through their career span. Adm Sci. 2017;7(17):1-13. https://doi.org/10.3390/ admsci7020017

57. Kihnula N. Learning Clinical Competence with Mobile Technology in Nursing Education: A Descriptive Literature, Helsinki Metropolia University of Applied Science; 2017.

58. Melnyk BM, Gallagher-Ford L, Zellefrow C, Tucker S, Thomas B, Sinnott LT, et al. The first US study on nurses' evidence-based practice competencies indicates major deficits that threaten healthcare quality, safety, and patient outcomes. Worldviews Evid Based Nurs. 2018;15(1):16-25. https://doi.org/10.1111/wvn.12269 PMid:29278664 